\title{
Penerapan Metode Tanya Jawab Dalam Meningkatkan Pemahaman Teks Dengan Membaca Intensif dan Membaca Teks Drama
}

\author{
NURLAILI \\ Sekolah Dasar Negeri 023 Pandau Jaya \\ Jln. AR. Rahim IV No. 1 Siak Hulu, Kampar \\ E-mail : nurlaili@yahoo.com
}

\begin{abstract}
Learning Indonesian m engenai understand the text into a relatively elusive subject, during the teachers use the lecture method and presumably through the use of question and answer method can be more effective in teaching. Through action research methods classes in primary schools and the data collected through tests and observation and analyzed with descriptive techniques. The obtained results of the study that the application of teaching methods debriefing in order to enhance students 'understanding of intensive reading and reading drama in the classroom texts on subjects Indonesian was able to increase the students' understanding.

Keywords:
\end{abstract}

Keywords: Question and Answer Methods, Understanding Students

Pembelajaran merupakan suatu sistem yang unsur-unsurnya saling berinteraksi. Keberhasilan pembelajaran antara lain ditentukan oleh keterampilan guru dalam memilih dan menerapkan metode yang tepat dan strategi pembelajaran yang digunakan untuk peserta didik.(Laila, 2009)

Pentingnya peranan guru dalam pembelajaran siswa merupakan bentuk kompetensi yang dimiliki guru, guru dapat mentransfer ilmunya sehingga siswa benarbenar mengetahui dan memahami serta dapat melakukan dalam kehidupan sehari-hari. Hal ini dapat dilihat dari mata pelajaran bahasa indonesia, pelajaran bahasa indonesia salah satunya adalah dalam hal membaca intensif dan membaca teks drama, siswa selain dapat mengetahui isi teks, diharapkan juga siswa dapat menyampaikan kritik dan sarannya dalam teks yang dibaca tadi. Hal ini menjadi suatu bukti bahwa siswa memang benarbenar dapat membaca dan dapat menganalisis secara kritis terhadap teks yang dibacanya.

Untuk dapat mengetahui apakah siswa dapat mengetahui dan memahami isi teks yang dibaca, maka siswa perlu menyampaikannya di depan kelas dihadapan para siswa lainnya dan di hadapan guru kelas yang mengajarkan mata pelajaran bahasa indonesia tersebut. Selain itu juga siswa lain dapat mengajukan sanggahan terhadap apa yang diketahui dan dipahami oleh siswa tadi.

Metode Tanya jawab adalah cara penyajian pelajaran dalam bentuk pertanyaan yang harus dijawab, terutama dari guru kepada siswa, tetpi dapat pula dari siswa kepada guru. Metode tanya jawab adalah yang tertua dan banyak digunakan dalam proses pendidikan, baik di lingkungan keluarga, masyarakat maupun sekolah. Metode ini dapat diklasifikasikan sebagai metode tradisional atau konvensional. Dalam metode tanya jawab, guru mengajukan pertanyaan-pertanyaan dan siswa menjawabnya, atau sebaliknya siswa bertanya guru menjelaskan.

Dalam proses tanya jawab, terjadilah interaksi dua arah. Guru yang demokratis tidak akan menjawabnya sendiri, tetapi akan melemparkan pertanyaan dari siswa kepada siswa atau kelompok lainnya tanpa merasa khawatir dinilai tidak dapat menjawab pertanyaan itu. Dengan metode tanya jawab tidak hanya terjadi interaksi dua arah tetapi juga banyak arah. Ketika anak menanyakan tentang bilangan prima, sebagai misal, guru yang demokratis tidak akan menjelaskan sampai tuntas tentang apa itu definisi 
bilangan prima, dan kemudian memberikan contoh bilangan prima. Dari pertanyaan ini akan muncul beberap orang ayang akan berinteraksi di dalam pertanyaan tersebut. Dalam penggunaan metode mengajar di dalam kelas, tidak hanya Guru saja yang senantiasa berbicara seperti halnya dengan metode ceramah. melainkan mencakup pertanyaan pertanyaan dan penyumbang ideide dari pihak siswa.

Kasus di SD Negeri 023 Pandau Jaya, mengenai rendahnya pemahaman siswa dalam membaca intensif dan membaca teks drama. Ketercapaian pembelajaran dengan ketuntasan siswa dengan KKM 70 hanya $63 \%$ siswa yang tuntas. Sedangkan sisanya masih menjadi persoalan yang perlu mendapatkan perhatian dari guru kelas.

Oleh karenanya diduga dengan penerapan metode tanya jawab siswa akan semakin memahami membaca teks secara intensifMetode Tanya jawab adalah cara penyajian pelajaran dalam bentuk pertanyaan yang harus dijawab, terutama dari guru kepada peserta didik, tetapi dapat pula dari peserta didik kepada guru. Jika dilihat dari pengertiannya metode ini lebih menekankan interaksi antara guru dengan siswa.Interaksi yang dimaksudkan berupa bertanya dan menjawab pertanyaan. Pertanyaan yang diajukan oleh guru tidak hanya sekedar bertanya terkait materi pelajaran tetapi lebih kepada bimbingan untuk mencapai tujuan pembelajaran dan mengidentifikasi karakteristik siswa dalam belajar.

Menurut daryanto (2013), metode Tanya jawab digunakan untuk hal-hal seperti berikut:

a. Menciptakan suasana yang hidup (setiap peserta ikut serta dan aktif) dalam KBM

b. Menggali ide-ide peserta.

c. Memberikan rangsangan kepada peserta/siswa untuk merumuskan ide-ide yang tergalidengan menggunakan kalimat sendiri.

d. Mengetahui posisi pemahaman siswa terhadap tema yang dibahas.
e. Menciptakan kesempatan kepada siswa untuk mengonsolidasikan pemahamannya.

f. Memberikan kesempatan kepada siswa untuk berani komentar.

Metode Tanya jawab memiliki kelebihan dan kelemahan sebagai berikut:

a. Kelebihan metode Tanya jawab:

1) Pertanyaan dapat menari dan memusat perhatian siswa, sekalipun ketika itu siswa sedang rebut, yang mengantuk kembali tegar dan hilang kantuknya.

2) Merangsang siswa untuk melatih dan mengembangkan daya piker, termaksud daya ingatan.

3) Mengembangkan

$\begin{array}{lr}\text { keberanian } & \text { dan } \\ \text { keterampilan } & \text { dalam } \\ \text { menjawab } & \text { dan } \\ \text { mengemukakan pendapat. }\end{array}$

b. Kelemahan metode Tanya jawab:

1) Siswa merasa takut, apa lagi guru kurang mampu mendorong siswa untuk berani, dengan menciptakan suasana yang tidak tegang, melainkan akrab.

2) Tidak mudah membuat pertanyaan yang sesuai dengan tingkat berpikir dan mudah dipahami siswa.

3) Waktu sering banyak terbuang, terutama apabila siswa tidak dapat menjawab pertanyaan sampai dua atau tiga orang.

4) Dalam jumlah siswa yang banyak, tidak mungkin cukup waktu untuk memberikan pertanyaan kepasa setiap siswa. 
Ketika peserta didik tidak mampu berkonsentrasi, ketika sevagian besar peserta didik mebuat kegaduhan, ketika peserta didik menunjukan kelesuan, ketika minat belajar peserta didik berkurang dan sebagian besar peserta didik tidak menguasai materi yang telah guru sampaikan, ketika itulah perlu dipertanyakan factor penyebabnya dan usaha mencari jawaban secara tepat. Apa bila hal itu tidak dilakukan maka guru akan mengajar dengan sia-sia. Boleh jadi dari berbagai keadaan tersebut salah satu pnyebabnya adalah factor metode.Karena hal itu, efektifitas penggunaan metode perlu dipertanyakan.(Masjoko, 2010)

Berdasarkan uraian latar belakang tersebut, maka dapat diuraikan pada bahasan berikut ini

\section{METODE}

Metode yang digunakan dalam penelitian ini adalah metode penelitian tindakan kelas. Penelitian tindakan kelas (PTK) tentu berbeda dari penelitian kelas (classroom research). PTK termasuk salah satu jenis penelitian kelas karena memang penelitian tersebut dilakukan di dalam kelas. Namun penelitian kelas yang dapat didefinisikan sebagai penelitian yang dilakukan di dalam kelas, mencakup tidak hanya PTK, tetapi juga berbagai jenis penelitian yang dilakukan di dalam kelas. Penelitian kelas yang terkenal adalah penelitian yang dilakukan dengan menggunakan cara Flanders, yang mengamati proporsi berbicara antara guru dan siswa. (Wardani, 2010)

Yang menjadi subjek penelitian tindakan kelas ini adalah guru bersama dengan siswa di kelas VI SD N 023 Pandau Jaya Kabupaten Kampar yang berjumlah 30 orang. Tindakan yang dilakukan dalam penelitian ini adalah memberikan bahan bacaan kepada siswa untuk dibaca teksnya kemudian siswa diminta untuk menyampaikan di ruang kelas dan melakukan tanya jawab dengan siswa lain dan dengan guru kelas. Karena keterbatasan waktu, penelitian tindakan kelas ini hanya dilaksanakan sebanyak 3 siklus masingmasing siklus dilaksanakan selama 1 bulan.

Teknik pengumpulan data dari penelitian tindakan sekolah ini adalah melalui data kualitatif yang diperoleh dari observasi, pengamatan, maupun wawancara. Analisa data yang digunakan dalam penelitian ini adalah analisa data kualitatif yang bersumber dari data primer maupun empiris. Melalui analisa data ini, dapat diketahui ada tidaknya peningkatan pemahaman siswa dalam membaca intensif dan membaca teks drama pada mata pelajaran bahasa indonesia melalui penerapan metode mengajar tanya jawab yang merupakan fokus dari penelitian tindakan kelas ini.

\section{HASIL}

Penelitian tindakan kelas (PTK) ini dilaksanakan dalam tiga siklus. Hal ini dikarenakan keterbatasan waktu yang tersedia, serta dengan tiga siklus sudah penulis anggap cukup untuk peningkatan pemahaman siswa dalam membaca intensif dan membaca teks drama pada sub pelajaran membaca mata pelajaran bahasa indonesia di kelas.

Pada siklus pertama pemahaman siswa pada isi teks dinyatakan kurang, yang mendapai $63 \%$ dan ini menunjukkan bahwasanya mereka kurang paham. Setelah selesai satu siklus maka diadakan refleksi mengenai kelemahan atau kekurangan dari pelaksanaan tindakan pada siklus pertama. Refleksi dilaksanakan bersama-sama berkolaborator untuk menentukan tindakan perbaikan pada siklus berikutnya. Dari hasil refleksi dapat diambil suatu kesimpulan bahwa perlu penerapan metode tanya jawab kepada siswa dalam memahami isi teks perlu mendapatkan penguatan pada siklus berikutnya.

Pada siklus kedua pemahaman siswa pada isi teks dinyatakan cukup, yang mendapai $76,7 \%$. siklus ketiga pemahaman siswa pada isi teks dinyatakan paham, yang mendapai $90 \%$. 


\section{Gambar 1 : Siklus Tindakan}

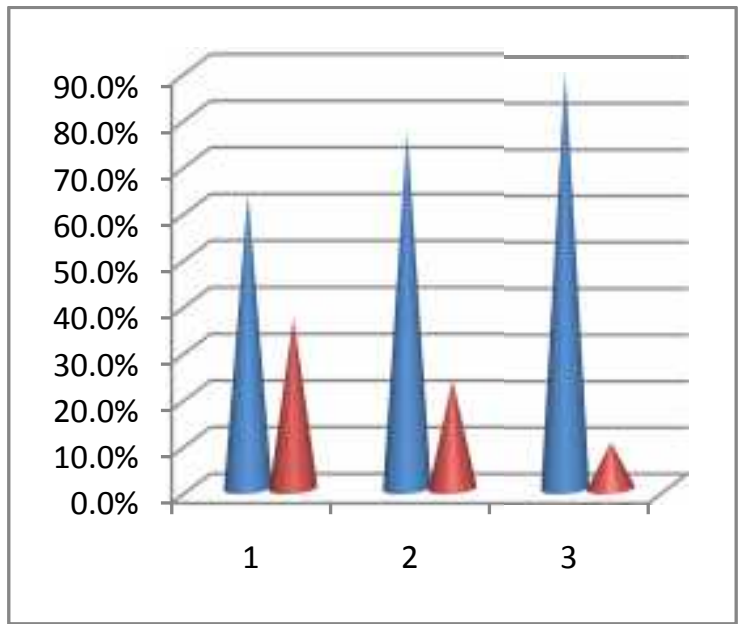

\section{PEMBAHASAN}

Berdasarkan analisis data, dari penelitian ini dapat ditarik kesimpulan bahwa, penerapan metode mengajar tanya jawab dalam rangka meningkatkan pemahaman siswa membaca intensif dan membaca teks drama di kelas pada mata pelajaran bahasa indonesia ternyata mampu meningkatkan pemahaman siswa.

Data yang diperoleh menunjukkan bahwa setelah dilakukan penerapan metode mengajar tanya jawab, maka terbukti adanya pengaruh yang ke arah yang positif dalam meningkatkan pemahaman siswa terhadap isi teks, penekanan ini dilakukan dengan memberikan waktu kepada siswa untuk membaca dan memperpanjang waktu tanya jawab.

Sebagaimana disampaikan oleh Yulianti. Melalui pengumpulan data dalam penelitian ini dilakukan dengan metode tes. Data yang didapatkan selanjutnya dianalisis dengan metode analisis deskriptif kuantitatif. Hasil penelitian menunjukan bahwa skor rata-rata keterampilan membaca yang diperoleh siswa pada siklus I adalah 66,16. Setelah diadakan perbaikan pada siklus II skor rata-rata hasil belajar membaca siswa sebesar 80,16 . Ini berarti terjadi peningkatan keterampilan membaca siswa dari siklus I ke siklus II sebesar 17,33 (Yulianti, 2013)

Hasil penelitian Yunus, bahwa dalam membaca teks mencapai $70,58 \%$ sudah memperlihatkan kriteria mampu. Serta yang kurang mampu mencapai $29,42 \%$. Sebagian besar siswa SDN 3 Tapa Kabupaten Bone Bolango sudah mampu membaca teks dengan penerapan model Snowball Throwing.(Santi Yunus, 2013)

Kemudian penelitian lainnya bahwa penerapan pembelajaran CIRC dapat meningkatkan keterampilan membaca siswa. Hal ini dapat dilihat dari hasil observasi siswa, dengan nilai tuntas pra siklus adalah $15,79 \%$, siklus I sebesar $52,63 \%$ dan Siklus II mendapatkan hasil maksimal sebesar $89,47 \%$. Saran yang dapat diberikan yaitu guru hendaknya dapat menmukan model pembelajaran yang tepat dalam pembelajaran membaca dan menulis permulaan dan dapat kreatif dalam menentukan strategi dan alat pembelajaran guna meningkatkan kemampuan belajar membaca dan menulis permulaan untuk memperbaiki kualitas pembelajaran. (SUYATMI, 2013)

\section{SIMPULAN}

Kesimpulan yang dapat diambil dalam penelitian ini adalah bahwa penerapan metode mengajar tanya jawab dalam rangka meningkatkan pemahaman siswa membaca intensif dan membaca teks drama di kelas pada mata pelajaran bahasa indonesia ternyata mampu meningkatkan pemahaman siswa.

\section{DAFTAR RUJUKAN}

Daryanto. 2013.Strategi dan Tahapan Mengajar. Bandung: Yrama Widya

Djamarah, Syaiful Bahar., Zain, Aswan. 2010. Strategi Belajar Mengajar, Jakarta: PT Rieneka Cipta

laila, n. a. (2009). pengaruh pendekatan ctl (contextual teaching and learning) terhadap hasil belajar membaca pemahaman bahasa indonesia siswa kelas iv sd. cakrawala pendidikan, 28(3), 238-248.

masjoko. (2010). metode_belajar_mengajar.

p.ISSN: $2407-800 X \quad$ e.ISSN: 2541-4356 
santi yunus. (2013). penerapan model snowball throwing dalam membaca teks pada siswa kelas iii sdn 03 tapa kabupaten bone bolango. universitas negeri gorontalo, 2013.

suyatmi. (2013). peningkatan keterampilan membaca dan menulis permulaan dengan metode cooperatif integrated reading and composition (circ) pada siswa kelas i sd negeri 02 jatipurwo tahun pelajaran 2012 / 2013.

wardani, k. (2010). hakikat penelitian tindakan kelas, 1-36.

yulianti, e. (2013). penerapan metode pq4r (preview, question, read, keterampilan membaca pada mata pelajaran bahasa indonesia di sd.

Sutikno, M. Sobry.2014. Metode Dan ModelModel Pembelajaran.Lombok:

Holistica 